\title{
Usos mediáticos del carisma de Dolores Ibárruri en los inicios de la Transición ${ }^{1}$
}

\author{
Vicente J. BENET \\ Universitat Jaume I de Castelló \\ benet@uji.es
}

Recibido: 10 de octubre de 2015

Aceptado: 30 de marzo de 2016

\section{Resumen}

El artículo ofrece un análisis de la función cumplida por Dolores Ibárruri, Pasionaria, durante la Transición a la democracia en España. Se centra en dos acontecimientos en los que la líder comunista tuvo un papel relevante: su retorno del exilio el 13 de mayo de 1977 y su presencia en la sesión inaugural de las primeras Cortes democráticas el 13 de julio de ese mismo año. A través del análisis del tratamiento de los medios de estos actos, se defenderá la idea del reciclaje del carisma, observando cómo un liderazgo carismático construido en un periodo histórico (la Guerra Civil) fue reutilizado en otro: la transición a la democracia. En este caso, con el fin de legitimar el proceso e instalar la idea de reconciliación en el relato de la Transición.

Palabras clave: Dolores Ibárruri Pasionaria, carisma, Transición democrática en España, medios de comunicación.

\section{How the media used the charisma of Dolores Ibárruri during the initial stages of the transition to democracy in Spain}

\begin{abstract}
The article analyzes the role of Dolores Ibárruri "La Pasionaria" during the Transition to democracy in Spain. There were two central events in which the Communist leader played a key role: the first was upon her return from exile on May 13th, 1977; and second was her presence at the inauguration of the first democratic Parliament on July 13 of that same year. By looking at how the media portrayed these events, it becomes clear that there was a recycling, so to speak, of her charisma: the charismatic leadership role that was constructed during the Civil War was later resuscitated during the transition to democracy. However in this case, it was used to legitimize the process of transition and infuse its narrative with an overtone of reconciliation
\end{abstract}

Keywords: Dolores Ibárruri Pasionaria, charisma, transition to democracy in Spain, mass media.

\section{Referencia normalizada}

BENET, Vicente J. (2016): "Usos mediáticos del carisma de Dolores Ibárruri en los inicios de la Transición”. Estudios sobre el Mensaje Periodístico. Vol. 22, Núm. 1 (enero-junio), págs.: 77-99. Madrid, Ediciones Complutense.

Sumario: 1. Introducción, planteamiento del tema y metodología. 2. El carisma de Pasionaria en el contexto previo a la Transición: función simbólica y reciclaje. 3. Raíces iconográficas y discursivas del carisma de Pasionaria. 4. La Transición, la lucha de símbolos y la construcción del relato. 5. Imágenes para el fin del exilio. 6. Las fotos de la reconciliación en el Parlamento. 7. Conclusiones. 8. Referencias bibliográficas.

1 Este artículo es producto del proyecto de investigación $\mathrm{I}+\mathrm{D}+\mathrm{i}$ La construcción mediática del carisma de los líderes políticos en periodos de transformación social: Del tardofranquismo a la Transición (HAR2012-23593), financiado por el Ministerio de Economía y Competitividad de España. 


\section{Introducción, planteamiento del tema y metodología}

La principal función política, simbólica, mediática e iconográfica cumplida por Dolores Ibárruri, Pasionaria, durante la Transición democrática española se podría condensar en un corto aunque intenso periodo de tiempo que se prolonga exactamente durante dos meses. Esto no resulta demasiado extraño en un momento político caracterizado por su desbocada aceleración. El periodo al que me refiero comenzaría con su llegada desde el exilio el 13 de mayo de 1977 y culminaría con el día de su entrada en el edificio de las Cortes por primera vez desde el final de la Guerra Civil. Este acontecimiento tendría lugar el 13 de julio del mismo año, en la sesión de constitución de la Cámara surgida tras las primeras elecciones democráticas desde 1936 celebradas un mes antes. No cabe duda de que tanto los antecedentes como las consecuencias que se extienden más allá de este marco temporal poseen también un indudable interés para entender el papel desempeñado por Pasionaria durante el proceso de cambio político y a ellos nos dedicaremos en otro estudio más amplio. En este artículo, sin embargo, nos centraremos en el intervalo de estos dos meses y, más específicamente, en el significado profundo de estos dos actos donde la líder comunista cumplió un papel decisivo. Para desarrollar la argumentación plantearé una metodología de análisis del discurso construido por los medios en torno a estos actos. Tanto desde el contenido de las noticias aparecidas en prensa como desde el aparato gráfico que las acompaña, observaremos como el discurso periodístico va estableciendo un relato de la transición que se convertirá en hegemónico. De este modo, partiendo de unas herramientas metodológicas propias del estudio de los medios de comunicación de masas, pretendo reconstruir el papel político de un carisma (que presentaré como un caso vinculado a un proceso de "reciclaje") y sus consecuencias en un contexto específico. El punto de llegada de este proceso de análisis será ofrecer una perspectiva del papel de Dolores Ibárruri en la Transición desde la historia de la comunicación social.

Los dos momentos escogidos para este estudio estuvieron cargados de un simbolismo que considero trascendental en el contexto político en el que se produjeron. A través de ellos, podremos observar una serie de operaciones discursivas e iconográficas, elaboradas a través de los medios de comunicación y principalmente de la prensa, que van a servir para definir el papel de Dolores Ibárruri como un icono denso, complejo y, en ocasiones, contradictorio. En resumidas cuentas, su efímero protagonismo político, prácticamente reservado para estos dos actos, revela algunos de los temores y también las aspiraciones que caracterizaban a amplios sectores de la sociedad española durante esos turbulentos años.

\section{El carisma de Pasionaria en el contexto previo a la transición: función sim- bólica y reciclaje}

¿Qué podía aportar esa anciana que vivía prácticamente retirada con su familia en Moscú a un país en tan rápida mutación? En primer lugar, Pasionaria condensaba gran parte del valor patrimonial y memorístico del Partido Comunista de España, el mejor organizado, el más grande en militancia y el más valeroso en su oposición a la dictadura de Franco. Era su líder histórica, su mayor figura carismática y llegaba a identificarse tanto con el partido como con el propio pueblo español (Cruz, 1999: 176). A 
los ojos de los militantes y simpatizantes, servía de aglutinante y apuntalaba su vertebración en la organización (Rueda Laffond, 2013:14). No hay que olvidar que, como parte consustancial a su cultura política, el movimiento comunista se caracterizó a lo largo de los años por "la adhesión ritual [de sus militantes] a una personalidad carismática nacional o internacional" (Ginard, 2013: 190). Pero, para amplios sectores sociales, su figura no agotaba todo su valor referencial únicamente en su identificación con el PCE. La proyección internacional del carisma de Pasionaria, la altura mítica que había alcanzado entre diversos sectores del antifranquismo, llegaba bastante más lejos que esta inmediata conexión y podríamos afirmar que incluso la desbordaba en la dimensión simbólica.

Consecuentemente, desde principios de los años 70 , su figura va a ser utilizada por la dirección del partido para trazar el camino de su adaptación a un contexto democrático europeo. Dentro de las maniobras del PCE para ir consolidando su lugar político como vanguardia de la lucha contra la dictadura ante la cercana muerte de Franco, Pasionaria había sido reactivada y llevada a la primera línea de la estrategia propagandística a través de su participación estelar en los tres grandes mítines organizados en París (20 de Junio de 1971), Ginebra (23 de Junio de 1974) y Roma (14 de Diciembre de 1975). Lo que se reveló en estos grandes actos de masas fue que su enorme poder de convocatoria trascendía los márgenes del partido comunista y llegaba a identificarse con la lucha antifranquista en general, al menos a los ojos tanto de un amplio sector de la emigración y de numerosos observadores, políticos e intelectuales europeos. No hay que olvidar que la emigración era decisiva como caladero de nuevos militantes. Tras el mitin de Montreuil, un militante de Annecy afirmaba que "... abre amplias perspectivas para el futuro del trabajo de nuestra organización y el fortalecimiento de la misma con nuevos ingresos y el cumplimiento de nuestras tareas"2. El acto celebrado en Montreuil suponía el regreso de Pasionaria al encuentro con las masas y con los medios de comunicación occidentales desde el gran mitin de Toulouse de 1947 (Benet, 2013: 45). Fue tan importante para la dirección del partido que se decidió hacer una película para ser mostrada a quienes no pudieron asistir. La película se concebía como un elemento esencial de movilización y propaganda asentada en el carisma de Dolores para vincularlo al de Santiago Carrillo (Sánchez-Biosca, 2014: 171). Al respecto del papel movilizador que podía cumplir el filme, otro militante de la célula de Amsterdam afirmaba: "La película es algo que, naturalmente, nos tiene muy interesados ya que, como sabéis, ahora disponemos de un centro que estamos creando, y dicho sea de paso, está despertando mucho interés en la emigración española. Este interés coincide con la decadencia del centro franquista"3. En las imágenes del mitin de Montreuil grabadas por cineastas afines al PCE y al PCF podemos observar muchos jóvenes que se dirigen ansiosos a escuchar a esa figura legendaria con sus pancartas y sus retratos. Además, una nueva generación que no había cono-

2 Carta firmada por Beltrán (Annecy, 14.07.71) AHPCE, Sección Emigración Política. Microfilm 1043.

3 Carta firmada por Juan, Responsable Político del Comité (Amsterdam, 13.07.71) AHPCE, Sección Emigración Política. Microfilm 1065. 
cido la guerra empezaba a cobrar un peso significativo en el partido (Falcón, 1996: 370) y Pasionaria era para ellos un punto de referencia que les conectaba con los mitos del pasado que no habían llegado a conocer, a pesar de que en algunas ocasiones la visión del mundo de Dolores Ibárruri, sus valores o sus aproximaciones políticas expresadas en las reuniones e informes para la dirección causaran estupefacción por su carácter desfasado y su limitado alcance intelectual en tiempos de sofisticadas y relamidas teorizaciones. Así ocurrió en el Pleno del Comité Central celebrado en París en Agosto de 1970 (Low, 1992: 193). En cualquier caso, todos estos desajustes quedaban de puertas para dentro. Pasionaria integraba en su figura pública un capital simbólico tan heterogéneo como variado que remitía hacia el exilio y el antifranquismo en general.

Esto se hizo todavía más patente en el gran mitin de Roma de diciembre de 1975. Franco acababa de morir y el partido buscaba un gran golpe de efecto convocando a las masas en un acto político que además sirviera de homenaje a Pasionaria en su 80 cumpleaños. Se trató, en palabras de Vázquez Montalbán, "de una operación de relaciones públicas formidable" que comenzó por una recepción a Pasionaria antes del acto por parte del alcalde democristiano de la capital italiana (Vázquez Montalbán, 2005: 152). En la mesa presidencial del mitin, junto a Dolores, se encontraba Enrico Berlinguer, Secretario General del PCI, junto con viejos y controvertidos símbolos del comunismo como Vittorio Vidali (el comandante Carlos de la Guerra Civil); pero también la acompañaban algunos personajes representativos de la oposición al franquismo más moderada y vinculada a la Junta Democrática, como José Vidal Beneyto e incluso el opusdeísta Rafael Calvo Serer, antiguo gerifalte intelectual del franquismo pasado esos años a la oposición al régimen. El carisma de Pasionaria, por lo tanto, se proyectaba sobre una amplia gama de sensibilidades políticas.

No es menos cierto que, en los sectores sociales más identificados con el franquismo, la reactivación de su figura sirvió para agitar de nuevo los espectros de la Guerra Civil. Volvieron a aparecer los libelos sobre supuestos y fantasiosos crímenes cometidos por Pasionaria que la prensa del periodo agitaba sin tapujos, sobre todo tras la muerte de Franco. Tampoco fueron evitados los titulares periodísticos amenazadores sobre la sed de venganza con la que podrían retornar los comunistas ${ }^{4}$. Pero más allá de estos actos típicos de manipulación de los temores de una sociedad en proceso de cambio por parte de sectores bunkerizados e inmovilistas, el aspecto más destacado de su figura es que concitaba una serie de referentes relacionados con el pasado que podían ser procesados y reciclados en el proceso político que se estaba poniendo en marcha. De esto no tardarían en darse cuenta incluso los grupos políticos más conservadores. Pasionaria era, ante todo, pasado vivo impostado en el presente. Un referente de enorme potencia simbólica que podía ser puesto a servicio del proceso político en marcha y no sólo, precisamente, a conveniencia del PCE. Se trataba, en suma, de reciclar toda esa fuerza carismática para conseguir nuevos fines, los que debían servir para construir un relato de la Transición.

4 El Alcázar, 14.05.77, p. 10; ABC, 08.04.77, p. 13. 


\section{Raíces iconográficas y discursivas del carisma de Pasionaria}

Para entender la proyección imaginaria de Dolores Ibárruri, es necesario partir de los rasgos que sirvieron para convertirla en un referente carismático. Su liderazgo se forja, como bien sabemos, en el contexto de la Guerra Civil, en sus eficaces discursos en mítines o en la radio y en su vigorosa e infatigable presencia en actos de apoyo a la República o en el frente, ampliamente tratados por los medios del momento. Esas imágenes permanecían más o menos latentes en el imaginario asociado a su figura. Sin embargo, en 1977, la situación era distinta. Para empezar, su propia presencia física contrastaba enormemente con la de la mayoría de personas que estaban protagonizando el proceso de cambio político. En la fecha de su retorno del exilio, Pasionaria era una anciana de 81 años. Aunque su aspecto se mantenía vigoroso y presentaba una actitud de cara al público casi siempre alegre y dispuesta, ya no podía transmitir la solidez y energía de antaño. En cualquier caso, la consistencia de su figura, su sobriedad y previsibilidad seguía haciéndola perfectamente reconocible con el referente de los tiempos de la Segunda República. Su forma de vestir, de peinarse y de concebir su presencia física en los actos de masas no había cambiado prácticamente en cuarenta años y se había convertido en una iconografía estable y reconocible para todos. No sólo su imagen, también su modo de planear la locución de sus discursos, sus clichés y sus crescendos y trémolos emocionales, reflejan una autoconsciencia muy patente sobre las fortalezas de su consistencia carismática labrada en los tiempos de la guerra y en el contacto directo con las multitudes o un uso muy eficaz de los eslóganes y las frases combativas en la radio. Además, muchos de sus discursos se basaban en el argumento de la unidad popular contra el fascismo, de una lucha patriótica y nacional, semejante a la guerra de la independencia, que trascendía las estrategias concretas de cada partido frente a un invasor totalitario (Núñez Seixas, Faraldo: 2009: 407). En definitiva, las características esenciales de su figura, fosilizadas desde los orígenes, las resume en una embelesada descripción Teresa Pàmies aparecida en una de las biografías que acompañaron la reactivación de la figura de Pasionaria en los albores de la transición. Pàmies se remite a una de las célebres intervenciones de Pasionaria, la realizada en el Congreso de los Diputados en junio de 1936, poco antes del estallido de la Guerra Civil:

"Dolores Ibarruri vestía de negro y, pese al calor de junio, con manga larga. Nunca enseñó los brazos en público. No se concibe una figura dramática en manga corta. Sus gestos al hablar, esos gestos que ni Margarita Xirgu podían superar en patetismo, subrayaban cada una de sus palabras estremecedoras o huecas (también las pronunció) y casaban con unos brazos cubiertos de manga ancha, vaporosa, recogida en el puño. Iba pulcramente peinada, con el clásico moño recogido en la nuca, pendientes discretos en las orejas [...]. Alrededor del cuello, un pañuelo vaporoso, estampado en tonos grises y blancos, el famoso pañuelo de "Pasionaria", que alguna vez, en algún momento de su discurso, agarraba vigorosamente de los extremos para apoyar en él todo su cuerpo y mostrarse más alta todavía, más imponente, frente a esos señores que la escuchaban como quien oye llover o barruntaban Dios sabe qué respuesta". (Pàmies, 1976:74)

Por tanto, el magnetismo de Pasionaria partía de su físico y de sus sobrios aderezos para apuntar a un difuso campo semántico que traspasaba el nivel de la política y 
remitía en confusa amalgama a lo ético, lo político, lo religioso y lo humano. Algunos analistas como Manuel Vázquez Montalbán o Rafael Cruz han explorado abundantemente este terreno en sus estudios sobre la forma en la que su carisma se asentaba en sus rasgos físicos y en el modo en que se vestía y hablaba. Lo esencial de su potencia carismática es que era capaz de traspasar, a los ojos de las masas, el discurso político para apuntar hacia referentes más trascendentes y complejos, incluso de procedencia religiosa. Vázquez Montalbán no se reprime a la hora de equiparar la potencia evocadora de la líder comunista a las letanías lauretanas que hablan la Mater dolorosa, Mater amantísima o Gloria potens. O también la Madre de Gorki para todos los revolucionarios del mundo (Cruz, 1999: 205). En resumen, la idea de Pasionaria como madre sufriente y acogedora fue uno de los clichés más asociados a su figura. Se extiende a metáforas telúricas e incluso uterinas que reverberan en la transición. Como señalaba en 1980 Montserrat Roig: “... la Pasionaria es la Madre, la Gran Madre, y representa a la Tierra. Es el gran útero donde podían refugiarse los milicianos cuando, en el frente, temblaban de frío y de miedo. Al mismo tiempo, era la tierra, de ella venía" (Roig, 1980: 216).

\section{La Transición, la lucha de símbolos y la construcción del relato}

No cabe duda de que ese papel simbólico podía encontrar una nueva expresión y función política en el contexto de la transición. Como afirmé más arriba, se trataba de reciclar todo ese poder de evocación a las necesidades de los nuevos tiempos. Sin embargo, los años 70 estaban vinculados a una coyuntura, el final de la guerra fría, en la que el papel de Pasionaria presentaba aristas y contradicciones en relación a la estrategia del PCE. Su figura se identificaba en gran medida con la URSS. Incluso podríamos decir más. A pesar de las depuraciones, las autocríticas y los silencios, la figura de Dolores Ibárruri evocaba un cierto poso estalinista que desde los años 50 podía derivar en la peligrosa acusación del "culto a la personalidad" (Cruz, 1999: 182). Este aspecto había sido decisivo en los debates internos del partido que condujeron a que fuera asumiendo un rol secundario frente a la figura de Santiago Carrillo, sobre todo desde 1956 (Morán, 1986: 276). El hecho de haber pasado casi todo el exilio en la URSS, rechazando instalarse en Francia, confirmaba esta imagen. Asociados a su función simbólica, también emergían aspectos biográficos como la muerte de su hijo Rubén en la batalla de Stalingrado o su interés por centrarse en su discreta y acomodada vida familiar en Moscú, puntuada ocasionalmente por celebraciones y condecoraciones por parte de los dirigentes de los distintos países de la órbita soviética, así como esporádicos viajes por los países del telón de acero, Cuba incluida, que la convertían en un referente excesivamente marcado por su apego a las políticas del PCUS. Esto representaba un problema para la estrategia del PCE en ese momento, ya que, como es bien sabido, el partido había escenificado un alejamiento de la URSS desde la invasión de Checoslovaquia en 1968. Este acontecimiento marcó un punto de inflexión para los dirigentes, que comenzaron a diseñar nuevas estrategias homologables a las que llevaban a cabo los dos principales partidos comunistas de las democracias occidentales: el francés y el italiano. Sin embargo, la prensa de la transición reincidió abundantemente en este flanco débil de la estrategia eurocomunista de $\mathrm{Ca}$ - 
rrillo. Y no sólo la prensa más conservadora, la Autobiografia de Federico Sánchez de Jorge Semprún, Premio Planeta de 1977 y libro muy comentado esos años, también cumplió un papel importante en la caracterización del discurso aparentemente renovado del PCE al inicio de la Transición.

Efectivamente, la posición de Santiago Carrillo, se iba dirigiendo hacia un pragmatismo y un posibilismo que le permitiera trasladar a España un peso político semejante al del Partido Comunista Italiano. Las decisiones vinculadas a estos movimientos no siempre eran bien entendidas entre los cuadros y las bases. De hecho, en este contexto se produjo la escisión encabezada por una figura histórica como Enrique Líster, en desacuerdo con el alejamiento de la URSS. En 1973 se consolidaría con la fundación del PCOE con los desencantados del PCE. A pesar de todo esto, Dolores Ibárruri se mantuvo incólume en el apoyo a la organización en la que había militado desde hacia casi medio siglo, así como a su secretario general. Su actitud fue siempre la de mantener la disciplina orgánica del partido, aunque manifestara de vez en cuando su fidelidad a la URSS. Los medios de comunicación, sobre todo de la derecha, amplificarán y subrayarán los ocasionales exabruptos de fidelidad soviética de Dolores.

En cualquier caso, teniendo en cuenta todas estas dificultades que presentaba su figura, Dolores Ibárruri podía cumplir una función esencial para el PCE en esa coyuntura, precisamente como contrapeso en su adaptación a las nuevas reglas de juego. Desde la muerte de Franco, las cosas comenzaron a ir muy deprisa, y el PCE tenía que echar mano de todo su patrimonio simbólico para compensar los jirones de una identidad forjada en 40 años de exilio que iba dejando en el camino para adaptarse a los nuevos tiempos. Tras la legalización del partido el 9 de abril de 1977, el retorno Pasionaria se fue convirtiendo en un tema cada vez más recurrente en la prensa. Las noticias relacionadas con su inminente retorno comenzaron a proliferar, centrándose sobre todo en las dificultades para otorgarle el pasaporte. Al mismo tiempo, la presión en la calle se reflejaba en una consigna ("Sí, sí, sí... Dolores a Madrid") fraguada en el Mitin de Roma que era repetida tanto en múltiples manifestaciones como en una canción interpretada por Ana Belén en esa intensa corriente emocional que va desde la matanza de abogados comunistas en su despacho de la calle Atocha de enero de 1977 hasta las elecciones del 15 de junio de ese mismo año.

Toda esta presión por recuperar el mito coincidía con otro acontecimiento de una importancia fundamental en el terreno de la lucha de símbolos. Apenas una semana después de su legalización, el primer Comité Central del Partido celebrado en España desde el final de la guerra decidió despojarse de algunos de los referentes esenciales de su patrimonio simbólico que además eran seña de identidad de la larga lucha antifranquista. Aceptaron la monarquía y el abandono de la bandera republicana, asumiendo a cambio la rojigualda tradicional. Como sentenció Carrillo "La opción hoy no está entre Monarquía y república, sino entre dictadura y democracia"5. Esta frase es repetida por Dolores Ibárruri en una entrevista aparecida en Interviú la semana antes de su llegada del exilio, aunque con un cambio de términos que resulta bastante

5 María Antonia Iglesias: “Santiago Carrillo: "La opción hoy no está entre Monarquía y república, sino entre dictadura y democracia" Informaciones, 16.04.77, p. 4. 
sintomático: “...el problema fundamental hoy no es Monarquía o República, sino democracia o neofascismo" ". En cualquier caso, el giro estratégico en los símbolos demolía algunos puntales del pasado del PCE que resultaban difíciles de admitir por muchos de sus militantes, sobre todo teniendo en cuenta que ninguno de los otros partidos de la izquierda, ni siquiera el PSOE, habían llegado a tanto en ese momento. El número de Mundo Obrero que daba cuenta de esa reunión del Comité Central (47.15, 10 abril de 1977) y de la rueda de prensa posterior enlazaba directamente la aceptación de la bandera monárquica (por una votación de 169 votos a favor, ninguno en contra y 11 abstenciones) con la afirmación por parte de Carrillo de que "el regreso de Dolores... va a tener lugar en los próximos días. No puede retrasarse. Y además, no va a provocar ningún movimiento telúrico, ningún seísmo. Va a ser el regreso de una española que tiene derecho a vivir en su Patria". El retorno de Dolores Ibárruri ayudaba en esa coyuntura, por lo tanto, a ofrecer una compensación en el terreno simbólico a tantas renuncias.

En este sentido, Pasionaria acabaría por ser incorporada al relato que se iría convirtiendo en hegemónico de la transición de estos momentos. Y lo sería a través de un concepto que había formado parte del discurso del PCE desde hacía dos décadas. Me refiero a la idea de "reconciliación nacional" promovida por Carrillo desde 1956. En la misma entrevista a Interviú la semana previa al retorno, realizada por teléfono a su casa en Moscú, Dolores dejaba clara esta idea programática. Afirmaba Pasionaria: “... todas mis actividades han estado orientadas y dirigidas hacia España al objeto de poner fin al odioso régimen franquista y de posibilitar la reconciliación entre los españoles, de cara a iniciar una etapa democrática en nuestro país" ". En suma, en el proceso de reciclaje del carisma de Pasionaria para el proyecto político de la transición, podemos observar tres objetivos que se adhieren tanto a su consistencia iconográfica como a su bagaje y legado que serán utilizados para el nuevo contexto. La primera es la de escenificar una imagen del retorno. Es decir, ilustrar con su llegada la idea del final del exilio y la superación de las heridas del pasado. La segunda, dependiente de la anterior, es la de diseñar una idea de reconciliación en la que los antiguos enemigos entran a formar parte de una sociedad normalizada y alejada de los enfrentamientos de antaño. La tercera idea, vinculada a la institucionalización de su figura como participante activa del proceso ejerciendo funciones de diputada, será, en suma, la de la legitimación de todo el proceso político de la transición. Todos estos elementos se condensarán en el trayecto de Pasionaria durante los aproximadamente dos meses en los que centramos nuestra reflexión.

\section{Imágenes para el fin del exilio}

Una de las cuestiones decisivas en el relato de la transición tenía que ver con la gestión del pasado. Asimilarlo al proceso político suponía afrontar al menos tres aspectos que determinaban las biografías políticas de sus protagonistas: la Guerra Civil, el

6 "Dolores Ibárruri "La Pasionaria": "Sigo siendo la misma". Última entrevista en Moscú" Interviú $\mathrm{n}^{\circ}$ 51, 5-11 de mayo, p. 26.

7 Ibídem, p. 25. 
exilio y el papel cumplido por cada uno de ellos durante la dictadura. Muchos de los protagonistas del cambio pertenecían a una generación más joven que no había participado en la guerra. No obstante, sí que habían ocupado cargos relevantes en la maquinaria de la administración franquista o habían desarrollado sus trayectorias al amparo de su manto institucional. Por este motivo, manejar el pasado se convirtió en un asunto muy sensible para unas carreras políticas que buscaban partir de un adanismo sin mácula. En cierto modo, un pacto implícito funcionó para no sacar a colación las responsabilidades políticas personales de las figuras más destacadas (Morán, 1991: 78), a pesar de que espectros como el de Paracuellos acompañaron frecuentemente a Carrillo en los medios de la derecha. En cualquier caso, esta más o menos velada ocultación de las trayectorias personales no debería entenderse como un pacto de silencio sobre el pasado, tal como señalan algunas de las voces actuales más críticas con el proceso. La transición fue también un momento en el que se produjo una amplia producción historiográfica sobre la Guerra Civil que alcanzó desde la investigación científica hasta las colecciones por fascículos o revistas dirigidas al gran público (Juliá, 2006: 60-61). Es cierto que el enfoque predominante de esa recuperación del pasado se hizo a través de grandes generalizaciones (la Guerra Civil explicada como choque entre ideologías en el contexto de los totalitarismos de los años 30). Pero detrás del proceso de la amnistía de octubre de 1977 (Aguilar, 1996: 262; Juliá, 2006: 70) hubo también un proceso de revisión del pasado que no fue tan frívolo ni superficial como algunos de los críticos de la transición nos quieren dar a entender.

El retorno de Pasionaria se planteaba, dentro de este contexto, como un elemento muy importante en la construcción del relato de la transición. Suponía dar una imagen al retorno del exilio. Debía escenificarse, por lo tanto, como un acto en el que el pasado se incorporara de manera engrasada y eficaz al acelerado proceso político que se vivía en el primer semestre de 1977. No hay que olvidar que el tema del exilio dejaba al descubierto una herida, todavía latente desde el final de la guerra, que no había acabado de cerrarse. Esa herida, desde luego, tenía una dimensión privada, personal, relacionada con miles de personas que habían tenido que abandonar su país, sus casas, sus profesiones y sus proyectos de vida y rehacerlos en otros lugares. Algunas de ellas eran escritores, intelectuales, académicos, científicos o incluso políticos que fueron retornando, siempre de manera muy discreta, desde los años 40 . Se trató de retornos tolerados que fueron permeando poco a poco en un ambiente que no dejaba de ser casi siempre hostil. La mayoría de los retornados se entregaron a una vida familiar y profesional sin proyección pública. Como consecuencia de todo esto, el retorno del exilio no poseía una imagen emblemática, no acababa de tener una ilustración susceptible de ser elaborada mediáticamente y de ser asumida en la esfera pública a través de iconos reconocibles.

Además del aspecto privado, obviamente también había una herida política que cerrar con la incorporación de los exiliados. Por decirlo brevemente, de su incorporación dependía también redondear la idea de legitimidad del proceso político que se estaba poniendo en marcha. Aunque desborda el objetivo de este artículo, hay que tener en cuenta que los exiliados poseían el bagaje de la legitimidad democrática asociada a las instituciones republicanas que había mantenido una continuidad a lo largo de toda la dictadura. Obviamente, este bagaje tenía un papel casi insignificante desde 
el punto de vista político, pero no era tan irrelevante en el sentido simbólico. Su fuerza se manifestó, por ejemplo, en el retorno del exilio del lehendakari Jesús María Leizaola o sobre todo del president de la Generalitat Josep Tarradellas para reinstaurar las instituciones que representaban. El modo en que se plantearon y negociaron estos retornos tuvo un valor simbólico, e incluso político a largo plazo, que no resulta desdeñable. Quizá no fuera tan importante que Dolores Ibárruri fuera miembro de la Comisión Permanente de las Cortes Republicanas desde 1937 y durante todo el exilio pero, como veremos un poco más adelante, el detalle no dejará de ser mencionado en el momento clave de su presencia en la Constitución de las primeras cortes democráticas. El asunto de la legitimidad se situaba, por lo tanto, en la médula del relato de la transición ya que, hasta este momento, el proceso político se apoyaba en el juramento de Juan Carlos de Borbón de los principios fundamentales del Movimiento el 22 de Noviembre de 1975 al acceder a la Jefatura del Estado como Rey de España. Principios que encontraban a su vez su legitimación en la noción de Victoria promovida por el franquismo desde el final de la guerra.

El retorno de Pasionaria se convierte, por lo tanto, en un problema tanto político como simbólico en el que se dirimen los equilibrios entre las fuerzas más bunkerizadas del régimen y las que aspiran a la aceleración del proceso. El relato de su vuelta del exilio tiene su punto de partida en el mitin de Roma y la promesa coreada por todos los asistentes del retorno a Madrid. La proyección mediática de este proceso en la prensa española comienza poco después, fundamentalmente con las noticias centradas en la petición de Dolores Ibárruri de un pasaporte en febrero de 1976 y la célebre respuesta de Manuel Fraga, Ministro de Gobernación en aquel momento, de que no poseía suficientes policías para protegerla. En este contexto, el del posible retorno, los medios recogían la polémica en términos que reverdecían los símbolos y eslóganes de la Guerra Civil. Términos, en suma, que definen una primera fase de predominio de un tono beligerante en el que se agitaban los fantasmas del pasado. El referente conceptual elegido fue uno de los más presentes en la memoria mitificada de la guerra: el "No pasarán", la consigna que resultó esencial en la consolidación carismática de Pasionaria desde su alocución radiofónica del 19 de julio de 1936. Hay que señalar que la frase se refleja por primera vez en los medios, precisamente, en un encuentro de Pasionaria con periodistas en el mitin de Roma de diciembre de 1975. Ante la pregunta de qué consigna daría en esos momentos a los camaradas, su respuesta fue: "pasaremos" (sic) (Melchor, 1976: 42). Nos encontramos evidentemente ante una paradójica inversión de sentidos con respecto al planteamiento de la consigna durante la guerra que puede dar pie a distintas interpretaciones. En cualquier caso, el eslogan se convirtió en recurrente en los medios a la hora de referirse tanto al retorno de Pasionaria como incluso a la propia legalización del PCE desde 1976. De este modo, la prensa conservadora asumió la inversión de roles planteada por Pasionaria con respecto a la guerra en una posición defensiva. En el número de Blanco y Negro de agosto de 1976 (p. 19) podemos encontrar el titular "No Pasarán" sobre fotos de Carrillo y Pasionaria tomadas en el mitin de Roma. La noticia se asienta en la posición de Fraga comentada anteriormente señalando además que, de las 250 solicitudes de pasaporte provenientes del exilio, la Dirección General de Seguridad aprobará casi todas menos un reducido grupo. El recurso a este lema encontrará su plas- 
mación con la salida de Carrillo de su breve encierro en prisión ocurrido durante la Navidad de 1976. La portada de Cambio 16 (n $266,10-16$ de enero de 1977) presentará un primer plano del Secretario general del PCE con el titular "El gobierno a los comunistas: Que pasen". La idea se repite en el encabezamiento del artículo principal (p. 8) e incluso en un artículo posterior que otorga protagonismo a Pasionaria y que se condensa bajo el titular: "Voy a pasar" (p. 14). Es muy interesante, por lo tanto, comprobar como esta retórica agresiva importada de la Guerra Civil está muy presente en estos momentos particularmente delicados previos a la legalización del PCE. Lo que podemos detectar, a partir de este primer momento, es un progresivo (pero no absoluto, como veremos a continuación) abandono de este tipo de referentes bélicos por unas estrategias más moderadas y difuminadas a la hora de describir los conflictos.

Pero al ritmo de los acontecimientos, esa primera fase beligerante fue atemperándose muy rápidamente. Un papel clave para preparar el retorno de Pasionaria y la normalización de la incorporación de los comunistas a la esfera pública lo cumplirá Rafael Alberti. El escritor gaditano, investido del aura de poeta, se había dedicado durante la guerra principalmente a tareas propagandísticas o artísticas y, por lo tanto, carecía de una pesada losa vinculada a su pasado. Fiel militante comunista durante el exilio, mantenía sin embargo el aire lírico e inofensivo de un intelectual dispuesto a contemporizar con los nuevos tiempos. De este modo, su regreso va a ser muy destacado por los medios de comunicación. Sobre su figura se apoyará una visión más calmada y serena de los comunistas tras la reciente legalización del partido. A punto de salir de su casa en Roma, Cambio16 ( $\mathrm{n}^{\circ}$ 281: 25-26) publicaba una entrevista en la que repasaba sus labores como agitador cultural en la guerra y su paso más discreto por el exilio. El mensaje político más explícito, elaborado a partir de difusos comentarios del poeta, era su alejamiento del estalinismo y su apoyo a la actual estrategia política. Una foto de Alberti saludando a los reyes Juan Carlos y Sofía en un acto en la embajada española en el Vaticano culminaba esa imagen normalizadora del inminente desembarco de los candidatos comunistas más señalados.

Cambio16 ( $\mathrm{n}^{\circ}$ 283: 35-37) volvió a ofrecer un largo reportaje del escritor sólo dos semanas más tarde celebrando su llegada y describiendo minuciosamente el viaje. El discurso sobre su labor como poeta y político se presentaba de nuevo sin demasiadas aristas, basado en las emociones del retorno, ocurrido finalmente el 27 de abril. La frase pronunciada por Alberti que hizo célebre ese retorno es bastante conocida (aunque hay algunas variaciones de detalle): "Yo salí todavía con el puño cerrado y llego con la mano tendida, buscando la fraternidad y la unidad de todos los españoles". Esta celebración del poeta que vuelve a su tierra en clave emocional siguió en más reportajes, como el que describe su primer viaje a su Cádiz natal con las fotos en las que aparece vestido con camiseta de rayas y gorra de marinero mientras habla con monjas, camina por el puerto, o da un pase de pecho con su chaqueta en una plaza de toros desierta (Cambio 16, $\mathrm{n}^{\circ}$ 291: 28-30). Incluso la prensa de la derecha perdía ante Alberti la beligerancia de unos meses antes ofreciendo una visión amable y acogedora del escritor gaditano recién llegado (Blanco y Negro no 3394: 31). Podríamos afirmar que el despliegue mediático en torno a la llegada de Alberti supuso un efecto de almohadillado a la inminente llegada de Pasionaria. Sus figuras aparecerían entrelazadas tam- 
bién, como veremos a continuación, en las imágenes de la sesión inaugural de las Cortes Constituyentes en julio.

Así pues, tres semanas después del retorno de Alberti y su amplia cobertura mediática, llegó el momento de Pasionaria. La polémica vinculada a la vieja retórica del "Pasaremos" desapareció también por completo en los medios y fue apuntalándose en un terreno discursivo más blando que de nuevo giró alrededor de lo emocional y lo familiar. El reportaje de Interviú ( $\mathrm{n}^{\mathrm{o}}$ 51:24-26) aparecido la semana previa a su llegada resolvía esta cuestión en el planteamiento gráfico. Una gran foto a color reciente de Dolores Ibárruri sonriente y relajada en su casa de Moscú a la izquierda iniciaba el artículo y contrastaba con algunas fotos de la Guerra Civil en blanco y negro (entre ellas la famosa de Pasionaria consolando al miliciano que acaba de ver morir a su hermano en batalla). La siguiente página, también en blanco y negro, ofrecía una imagen familiar de Ibárruri sosteniendo alegremente en brazos a su nieta junto con otra foto en la que aparecía con el líder indio Nehru y una acompañante identificada por el pie de foto como su hija Indira.

En cualquier caso, el seguimiento de su retorno se complicó por la rapidez de los acontecimientos. Una vez le fue entregado el ansiado pasaporte, Pasionaria decidió volver inmediatamente. El 13 de mayo, la portada de El País volvía a reproducir una vertiente familiar y amable con una foto en la que aparecía junto con su hija y sus nietos. El texto que acompañaba la foto anunciaba su inminente venida e insistía en que se esperaba que el regreso del exilio se celebrara sin grandes manifestaciones. Ese mismo día salía de Moscú, casi de manera imprevista. De hecho, Carrillo se encontraba en Sevilla por un mitin y tuvo que regresar precipitadamente a Madrid para estar presente en el encuentro con la prensa al día siguiente. Como le reprochaba veladamente un titular de Cambio16 (n 283: 45), Pasionaria iba "Por libre, como siempre". El viaje era largo e incluía una escala en el aeropuerto de Luxemburgo. Dolores Ibárruri rehusó encontrarse con los periodistas allá, pero el conocimiento de que se dirigía a España permitió organizar rápidamente un dispositivo de cámaras que recogieron el descenso por la escalerilla del avión y sus primeras pisadas en el asfalto de Barajas. Las imágenes cinematográficas de la llegada de Dolores Ibárruri, como ocurre con las de Alberti, nos muestran precipitación, rápidos saludos, desorientación, personajes abrumados por la rapidez de los acontecimientos. Se observan algunas cámaras de cine grabando al pie de la escalerilla, probablemente operadores próximos al partido (también está presente Juan Antonio Bardem, entre otros militantes). El plano general del descenso tomado desde el edificio del aeropuerto a gran distancia, que es el habitualmente difundido por la televisión, definía el emplazamiento en el que se situaba la mayor parte de la prensa. Entre ellos, el fotógrafo de EFE-Cifra Luis Alonso ${ }^{8}$, realizó la más utilizada por la prensa al día siguiente. Ocupó la portada de la edición de El País el 14 de mayo, justo por debajo de una foto del Conde de Barcelona que iba a ceder los derechos dinásticos a su hijo esa misma tarde. El titular que acompañaba la foto también era bastante neutro: "Dolores Ibárruri, en Madrid" (fig. 1). El mismo periódico daba cuenta al día siguiente de la amplia repercusión que había tenido la noticia en la prensa internacional. La precipitación e incertidumbre de la llegada y el modo en que se in-

8 Agradezco la identificación del autor de la foto al profesor Eduardo Rodríguez Merchán. 
tentó mantener al margen a los periodistas produjo que, de manera irónica, Diario 16 publicara en su portada: "La Pasionaria 'secuestrada"" (14.05.77: 1). Por su lado, $A B C$ volvía a utilizar la misma fotografía de Luis Alonso pero el tono de la noticia mantenía una posición decididamente beligerante. Bajo el titular: "Como un fantasma del pasado" se podían leer afirmaciones del tipo: "La Pasionaria pisaba en la tarde de ayer, nuevamente, tierra española; la misma tierra sobre la que... arrastran su dolor muchas familias de patriotas asesinados porque estorbaban a la definitiva implantación del imperialismo soviético en España" $(A B C, 14.05 .77: 9)$. El resto de la noticia insistía en el perfil totalmente prosoviético de Dolores Ibárruri y su menosprecio por el proyecto eurocomunista, un tema constante en la prensa de derechas. Por supuesto, El Alcázar alimentó esta idea con una posición aún más extrema. La noticia del regreso tenía como titular una aparente declaración de la "Vieja adicta estalinista": "El eurocomunismo es una imbecilidad". Otros dos subtítulos aparecían antes de entrar de lleno en la noticia: "Yo siempre he sido prosoviética" y "Nuestra venganza durará 4 veces 39 años, se lo prometo" (El Alcázar, 14.05.77: 10).

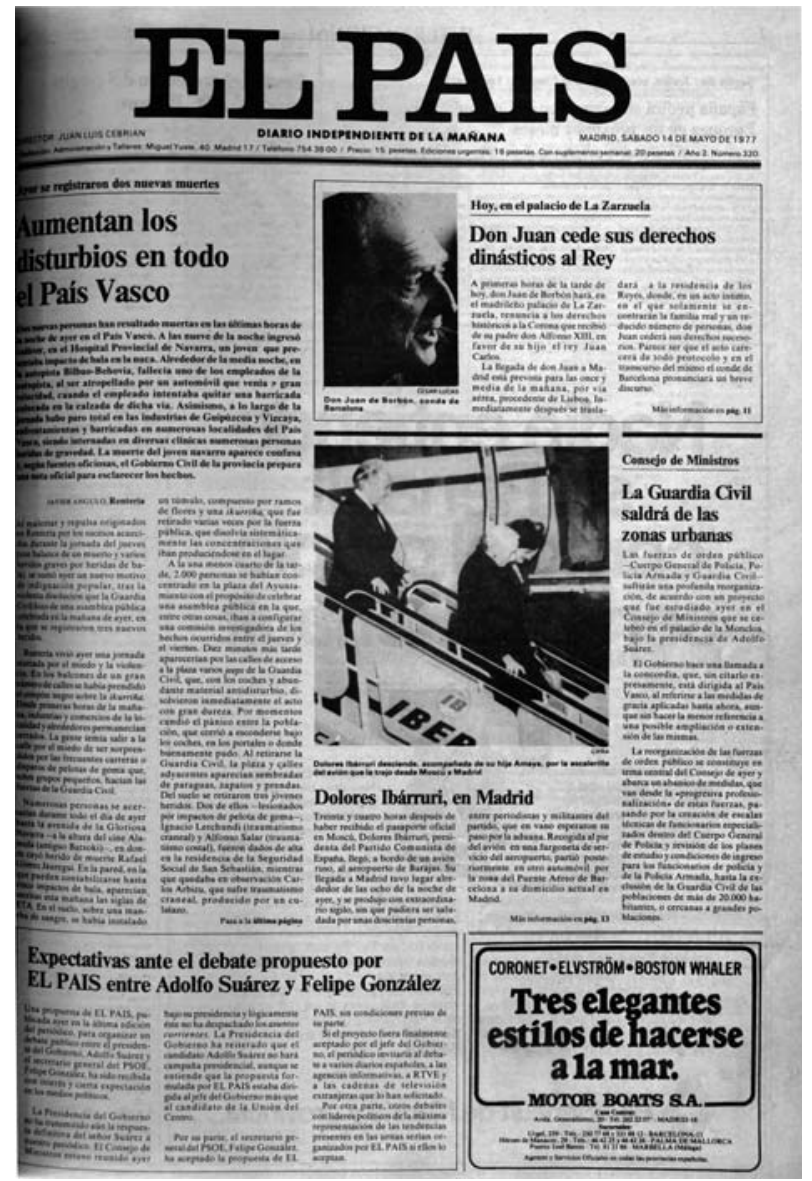

Figura 1. El País, 14 de mayo de 1977, portada 
El tratamiento de los media, por lo tanto, mostraba que en algunos sectores se mantenía una actitud beligerante y agresiva que se entrecruzaba con el clima de extremada violencia que se vivía en el país durante todo ese tiempo. No hay que olvidar los constantes atentados de ETA sobre los miembros del ejército y de la policía, la ofensiva del GRAPO y también los atentados de la extrema derecha. No cabe duda de que el discurso de la reconciliación todavía tenía un camino por recorrer en el ámbito mediático, pero no tan largo como parecía. En cualquier caso, se asentó una de las funciones fundamentales del acto: dar una imagen emblemática (y recurrente) a la idea del retorno del exilio. El pasado (amenazador para ciertos sectores, pero también detentador de un bagaje político y moral) volvía para formar parte del nuevo proyecto político y la mejor manera de condensar esa idea en una imagen poderosa y eficaz para los medios de comunicación se había conseguido con el retorno de Pasionaria.

Después de una rápida sesión fotográfica, el primer encuentro formal con la prensa se produjo al día siguiente, en el piso de la calle Sanjenjo en el que la alojó el partido nada más llegar. Carrillo ya estaba presente y aparecía junto a Pasionaria en la portada del ejemplar periódico Mundo Obrero ( $\mathrm{n}^{\circ}$ 47:20) dedicada al retorno de la líder. Federico Melchor hizo una crónica ampliamente ilustrada en la que entresacó algunas de las respuestas a las preguntas de los periodistas. Además de incidir en la dimensión emocional del momento, una de las formulaciones clave tiene que ver con la superación del pasado. Bajo la entradilla "La guerra es el pasado", Pasionaria afirmaba: “... no se pueden resucitar los viejos rencores. Vamos a vivir y trabajar por nuestras ideas, por hacer que lleguen al pueblo para lograr una transformación socialista de nuestro país. Pero sin nuevas luchas civiles ni guerras cruentas" (p. 8). El discurso de la reconciliación, esencial para la gestión del pasado, iría convirtiéndose en hegemónico a gran velocidad a partir de este momento. Para ello resultó esencial el proceso electoral de las elecciones del 15 de junio. Con el fin de sancionar sus resultados simbólicamente, fue necesario echar mano una vez más de la figura de Pasionaria.

\section{Las fotos de la reconciliación en el Parlamento}

El 13 de julio de 1977 se llevó a cabo el acto de constitución del Parlamento que había surgido de las primeras elecciones democráticas tras la dictadura de Franco. Se trató, sin duda, del momento culminante de la utilización de Dolores Ibárruri como símbolo en el proceso de la transición. Según la normativa prevista para esta sesión, se debía constituir una mesa provisional que organizaría la elección de la mesa interina tras la votación de los diputados. Puesto que esta mesa se formaba de acuerdo con criterios de edad (para la presidencia, de manera previsora, se había adoptado el criterio de que la ocupara el primer diputado en acreditarse ante la cámara, algo que correspondió a Manuel Fraile Poujade, de la UCD) Dolores Ibárruri iba a tener de nuevo un papel relevante a sus 81 años. Las vicepresidencias las ocuparían los diputados de mayor edad, mientras las secretarías corresponderían a los más jóvenes. A las diez de la mañana, los diputados ocupaban su sus escaños y Dolores Ibárruri y el resto de miembros de la mesa de edad fueron requeridos a ocupar su lugar en la tribuna de la Presidencia del Congreso.

El trayecto en el que descendió por los escalones del pasillo situado junto a los escaños que ocupaban del brazo de su camarada Rafael Alberti fue recogido por la mul- 
titud de fotógrafos diseminados por toda la sala. Se trataba de un momento cuya carga simbólica no se le escapaba a nadie. Los fotógrafos continuaron acompañándoles, captando hasta el menor gesto. Finalmente, obtuvieron la imagen definitiva de los ancianos comunistas flanqueando al Presidente en la mesa del congreso. Una vez constituida la mesa, se suspendió la sesión para organizar la votación que debería comenzar una hora y media más tarde. En total, el acto simbólico en el que Dolores Ibárruri tomó asiento en la presidencia del congreso duró apenas unos diez minutos, tal como recoge el Boletín de las Cortes de ese día. La cobertura, sin embargo, fue abrumadora. Posteriormente, cuando se volvió a las tareas de elección de la mesa interina, el lento proceso de votación hizo que la sesión se alargara. Algunas de las cámaras captaron ocasionalmente la creciente fatiga de Pasionaria y estas imágenes también aparecieron publicadas en la prensa al día siguiente.

El registro gráfico que reprodujeron los distintos periódicos y revistas ilustradas del momento fue enorme. Siguiendo la corriente del crescendo informativo que había supuesto la campaña electoral, el día de la constitución de la Cámara centraba un interés inusitado. Las fotos de los nuevos diputados charlando y ocupando sus escaños se combinaban con imágenes que pretendían ser alegóricas del proceso político que arrancaba en esa sesión. Pero, acompañando a ese despliegue de imágenes, hay otro aspecto esencial: el modo en que servían para articular un relato, una determinada narración de todo lo que estaba ocurriendo. Y en este sentido, la imagen de Pasionaria sirvió para distintos fines. La portada de El Alcázar, con poco disimulada ironía, mostraba una gran foto de Pasionaria junto a Alberti bajo el titular: "El futuro ha comenzado" (14.07.77: 1). El resto de los periódicos también interpretaron el acontecimiento de acuerdo con sus perfiles ideológicos, aunque la beligerancia de hacía apenas dos meses había desaparecido casi por completo.

En cualquier caso, la imagen más recurrente, la que fue más repetida por la prensa y en cierto modo sirvió para condensar todo el acto, no se dio dentro del hemiciclo de las Cortes. Ocurrió entre bambalinas, en un despacho adjunto. Se trató del encuentro de Dolores Ibárruri con el presidente Adolfo Suárez, justo antes de que se produjera la constitución de la mesa. Fue un saludo breve, de cortesía en el que fueron presentados y Pasionaria acabó por desearle suerte a Suárez. La fotografía fue portada en $A B C$ el 14 de mayo con un pie que decía "El presidente Suárez y Dolores Ibarruri: presente y pasado de la Historia española" (fig. 2). Mundo Obrero también utilizó esa imagen en su portada del número aparecido ese mismo día (13.07.77: 1) (fig. 3), al igual que lo hizo el periódico $\mathrm{Ya}$ (14.07.77: 1). Es en este sentido interesante el caso de El País. Aunque reservó para su portada una foto de Adolfo Suárez cruzándose con Felipe González en el hemiciclo, emplazó la foto del encuentro del presidente con Pasionaria en un lugar destacado, en la apertura de la noticia desarrollada en las páginas interiores. No sólo esto, la puso en el encabezamiento de la página, fuera del texto principal, dándole así un carácter emblemático que iba más allá de la mera ilustración de la noticia. Este énfasis del instante del encuentro fue acompañado además, ya en el interior del texto, por una serie de cuatro viñetas del humorista Peridis reproduciendo, con su habitual estilo de humor blanco, ese mismo acontecimiento. 

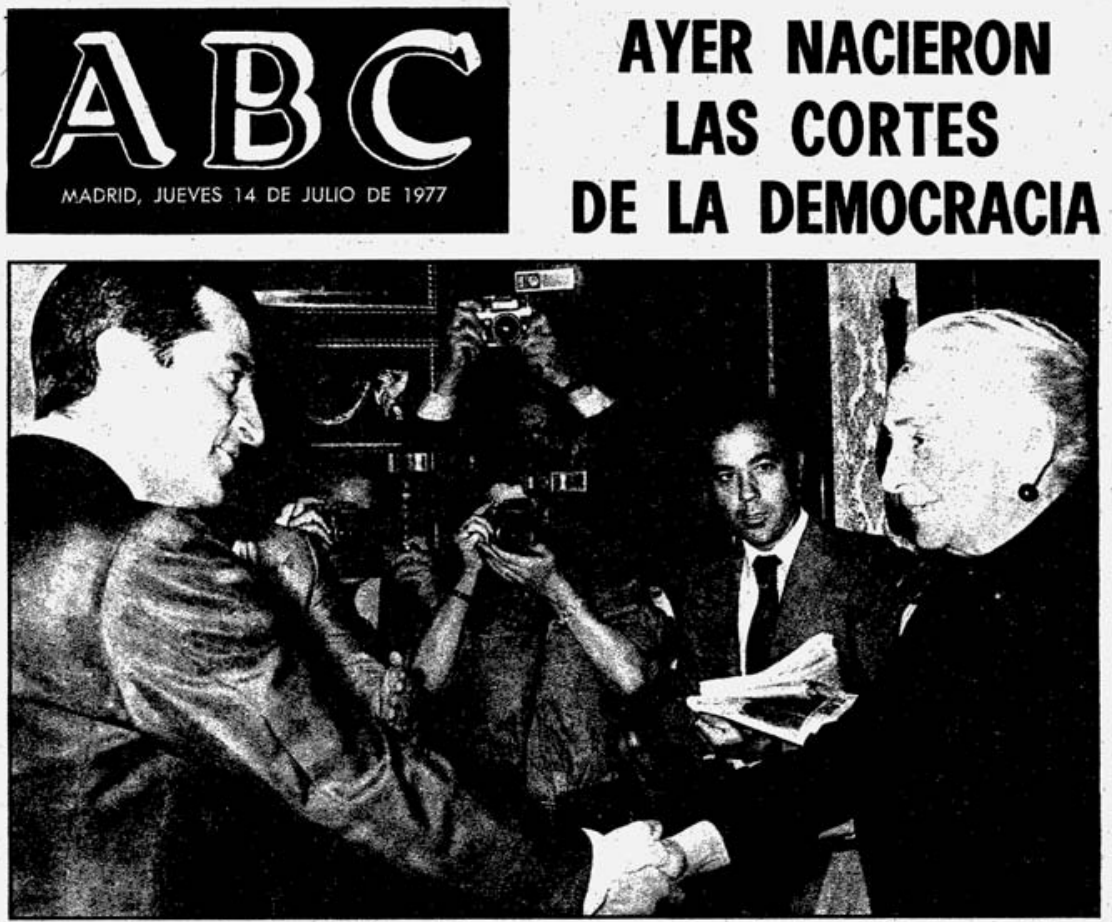

El presidente Suárez I Dolores Ibarruri: presente y pasado de la Historia española

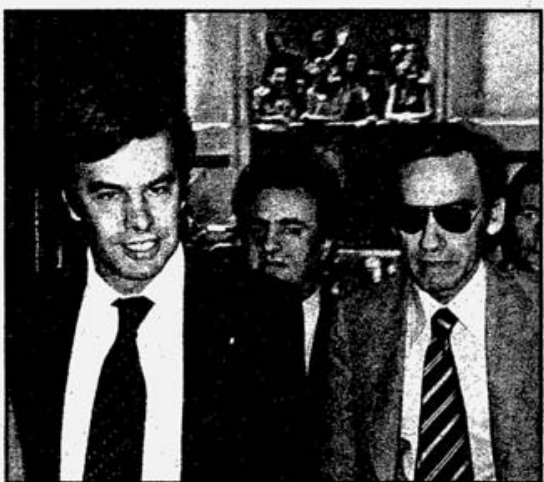

Felipe Gonzálex: día de estreno.

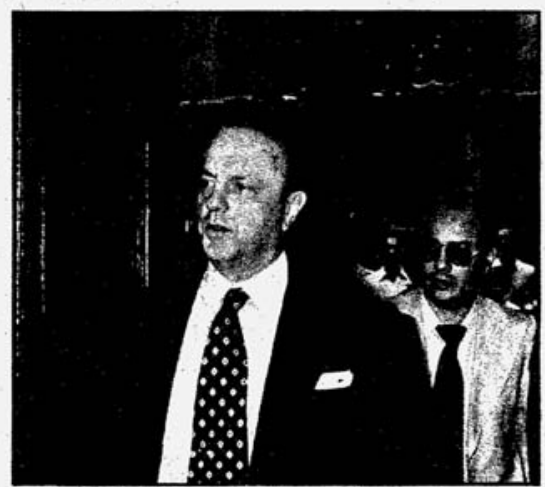

Fraga Iribarne: retorno a las Cortes.

\section{DOCUMENTO PERIODISTICO: 50 FOTOS}

Figura 2. $A B C, 14$ de julio de 1977, portada 


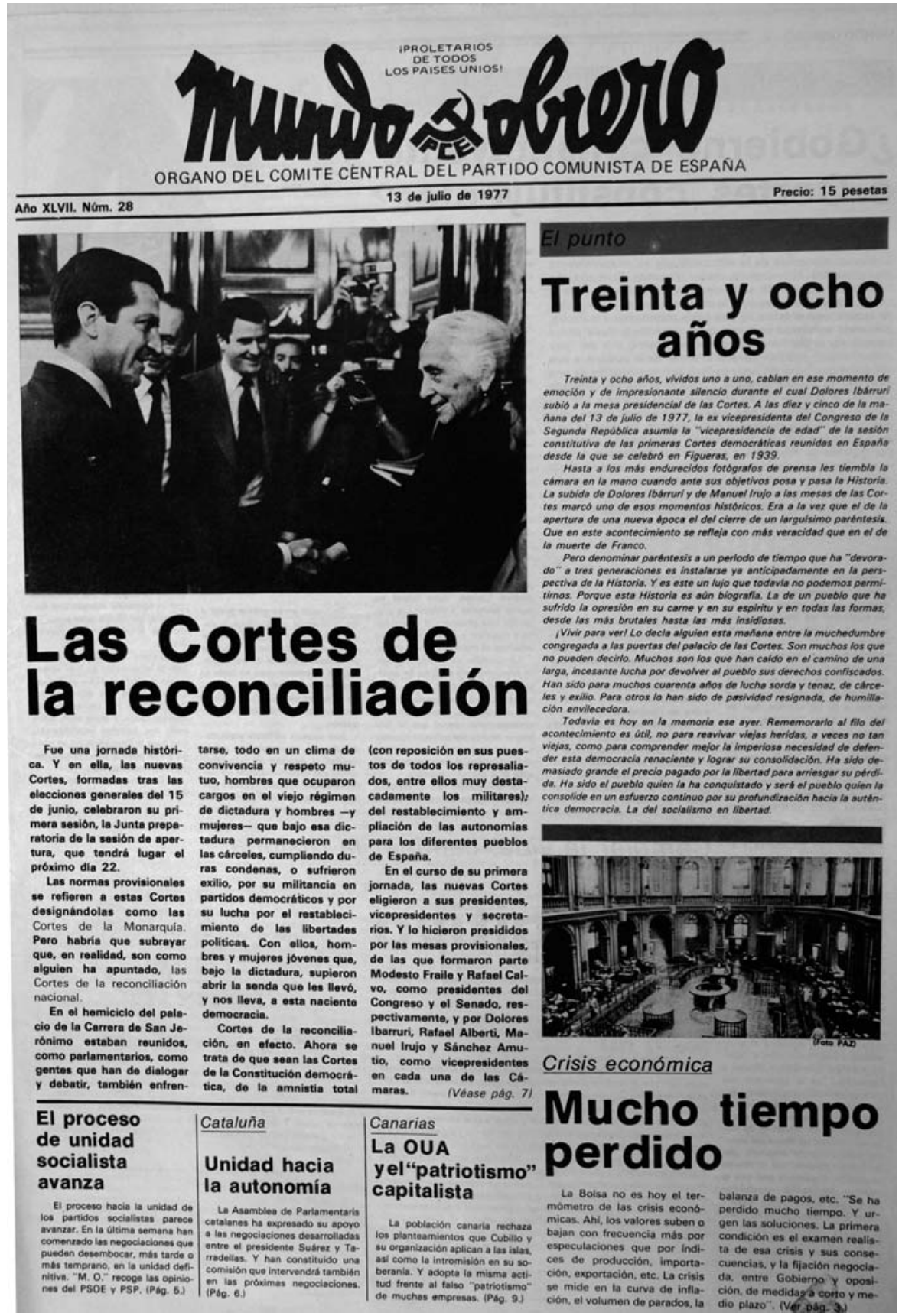

Figura 3. Mundo Obrero, 13 de julio de 1977, portada 
Es interesante, por lo tanto, observar cómo esta fotografía del presidente Adolfo Suárez estrechando la mano de Dolores Ibárruri se impuso como la imagen culminante, el auténtico emblema de un momento político crucial, el del arranque de las Cortes que acabarían siendo constituyentes. Todo el significado de ese acto institucional se condensaba en el encuentro de las dos figuras. Un encuentro no institucional, sino humano, justo al lado del hemiciclo donde se escenificaría el acto político unos minutos más tarde. En un lado, la más poderosa personalidad política en ese momento, el presidente Suárez. Junto a él, Pasionaria, que aunque fuera irrelevante políticamente (sobre todo teniendo en cuenta el número de diputados obtenidos por el PCE en esas elecciones) ofrecía una solución en el terreno simbólico. Pasado y presente, vejez y juventud, exilio y establishment postfranquista, se daban la mano en un gesto que fue rápidamente entendido como de reconciliación. Diario16, sobre una foto de los diputados socialistas sentados en su escaño, encabezaba su portada con tipografía de gran tamaño y a seis columnas con la frase "Reconciliación en las Cortes". Con letras más pequeñas, el subtítulo indicaba que "Antiguos combatientes republicanos y nacionales se reencontraron en el palacio de San Jerónimo" (14.07.77: 1). La evocación de la guerra apuntaba ya, no a un pasado, sino a un presente en el que los conflictos latentes comenzaban a resolverse. El relato dominante de la transición, como bien sabemos, convertiría esta idea en hegemónica.

Al fin y al cabo, la idea de reconciliación nacional, como ya hemos visto anteriormente, había sido postulada por el PCE desde 1956 y se había constituido como un lema propagandístico recurrente desde entonces. Consecuentemente, el Mundo Obrero del día 13 de julio, junto con la foto del encuentro de Suárez y Pasionaria, hizo uso del titular: "Las Cortes de la reconciliación". Esta palabra guiaba la argumentación de la noticia en el periódico de los comunistas que parece que había conseguido calar en el resto de los sectores del espectro político surgido tras las elecciones del 15 de junio. La otra línea del discurso del periódico era la de la legitimación del proceso que se estaba llevando a cabo. Mundo Obrero insistió más que ningún otro medio en el papel institucional que cumplieron Pasionaria y Alberti en la sesión. El acto aparecía ilustrado con una solemne foto frontal (realizada por Juan Barba) de la presidencia del congreso con un pie de foto que afirmaba que "... por una vez, la edad ha hecho justicia" (fig. 4). 


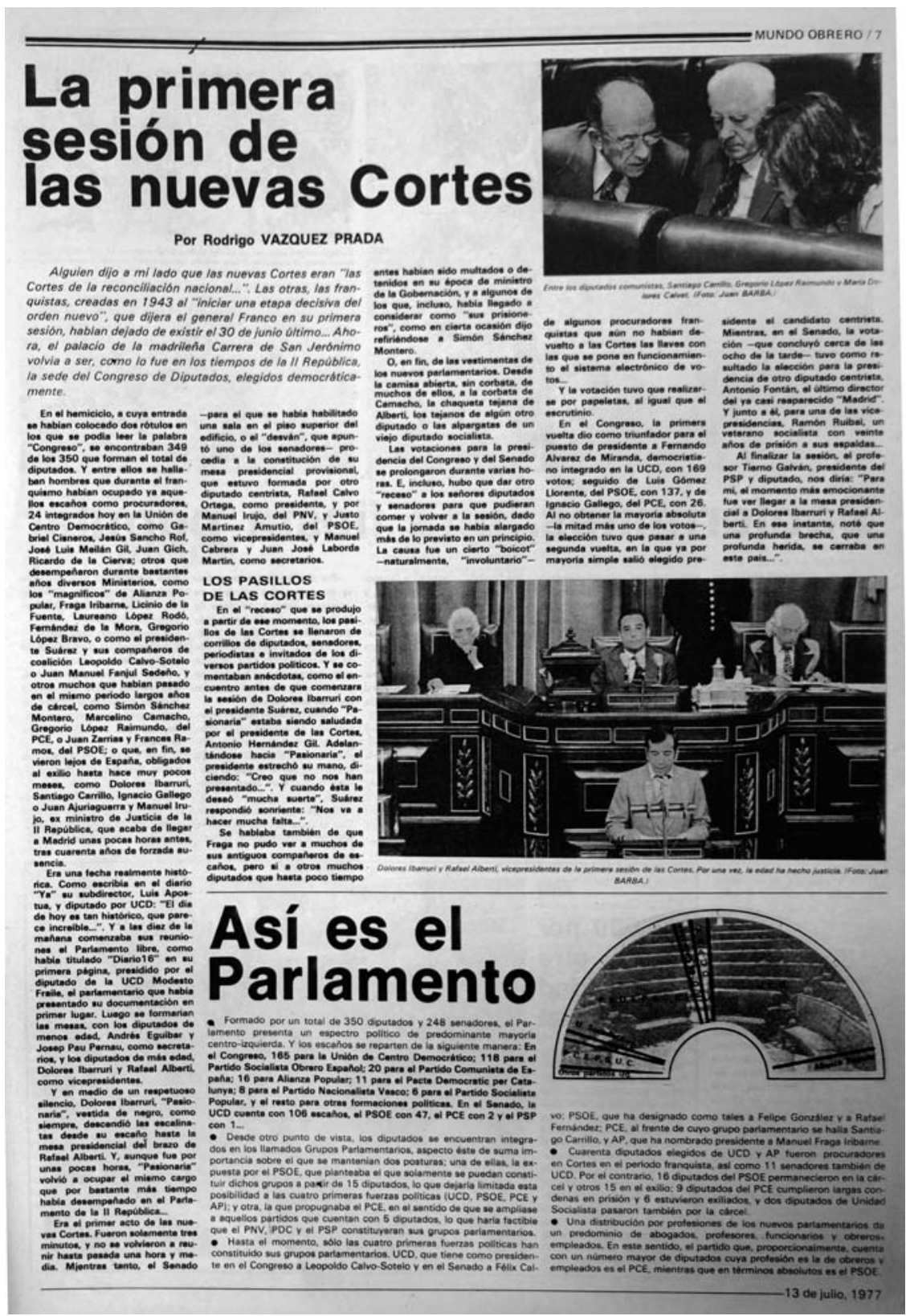

Figura 4. Mundo Obrero: 13 de julio de 1977, p. 7

En esa voluntad de legitimación, quizá compensando el precio político pagado por los comunistas en el proceso y sobre todo en las elecciones, Mundo Obrero ofrecía además un argumento de calado que pretendía llevar a un nivel históricamente más 
profundo tanto el acontecimiento como al papel cumplido por los comunistas en el mismo. Dicho brevemente, pretendía instaurar una idea de continuidad democrática con las Cortes de la segunda República. La crónica de la sesión, firmada por Rodrigo Vázquez Prada, aludía a que Pasionaria "... volvió a ocupar el mismo cargo que por bastante más tiempo había desempeñado en el Parlamento de la II República..." (Mundo Obrero, 13.07.77: 7). Dolores Ibárruri también alude a este efecto de continuidad en sus memorias (Ibárruri, 1985: 745). Sintomáticamente, casi veinte años de la sesión de la que hablamos, el argumento ya parecía cristalizado e incluso fosilizado en el relato de la transición, en el que los comunistas jugaron un papel tan esencial. En un libro de homenaje a Dolores Ibárruri en el centenario de su nacimiento (y por lo tanto seis años posterior a su fallecimiento), se defiende la idea de reconciliación nacional impulsada por el PCE y que permitió el normal desarrollo de las primeras elecciones democráticas tras la muerte de Franco. Aludiendo a su elección como diputada se afirma: "[Pasionaria] es reelegida después de la legislatura más larga de la historia de nuestro país la que va de 1936 a 1977, cuarenta y uno años como Diputada y desde el $1^{\circ}$ de febrero de 1937 miembro de la Diputación Permanente del Congreso de los Diputados, Cuarenta y un años de actividad parlamentaria ininterrumpidas. Cuarenta y un años de lucha por la democracia en España". (García Castillejo, 1995: 15 [énfasis míos]) ${ }^{9}$.

Desde luego, esta idea de la reconciliación no era patrimonio exclusivo de los comunistas. En el lado de aquellos que habían desarrollado una carrera política o profesional bajo el manto de la administración franquista se podían encontrar también algunos gestos propagandísticos en busca de esa idealizada superación del pasado. El más sonado, sin duda, sería la campaña de los XXV años de Paz orquestada por Fraga como Ministro de Información y Turismo en 1964 y que pretendía sustituir, en parte, el omnipresente discurso de la Victoria que había impuesto el régimen desde el final de la guerra. Ya en el proceso de la transición, la idea de la reconciliación se movió en torno a problemas políticos específicos como la amnistía, pero también conmemoraciones políticas como el 40 aniversario del bombardeo de Guernica en abril de 1977 (Aguilar, 1996: 275). En cualquier caso, la expresión más directa del proceso de reconciliación tomó cuerpo en una propuesta política específica y, probablemente, fue uno de los elementos que ayudarían a explicar su éxito. Ferrán Gallego describe el proceso de rápida creación de la UCD en la primavera de 1977, un momento en el que Suárez filtraba estratégicamente sus dudas en los medios de comunicación sobre la posibilidad de presentarse a las elecciones. La improvisación de este partido institucional se acogió de alguna manera al discurso de la reconciliación como uno de los principales aglutinantes. Gallego señala por ejemplo la sintomática tesis de Pedro J. Ramírez en $A B C$ a principios de mayo (que provocó un debate con Haro Tecglen) de que las listas de UCD estaban "llenas de elementos que habían sido adictos al antiguo régimen mezclados con quienes se habían opuesto a él, [planteando] la superación de la dialéctica franquismo/antifranquismo". (Gallego, 2008: 622). Como señala este his-

Todo sic. 
toriador, la formación de UCD acabaría por incorporar a su identidad como partido político, y desde esos momentos fundacionales, la idea decisiva de esta superación de los conflictos del pasado.

\section{Conclusiones}

Los resultados de esta operación quedaron patentes en los escaños conseguidos tras las elecciones, en los que la UCD obtuvo un triunfo clamoroso mientras el PCE se quedó en resultados más que modestos excepto en Cataluña. El discurso de la reconciliación propuesto por el establishment postfranquista resultó mucho más convincente que el de los comunistas. Pero señalar esta realidad política no nos debe alejar de la tesis defendida en este artículo, centrado en el valor de los símbolos y de la gestión del pasado para comprender el relato hegemónico de la transición. Resaltar el momento clave en el que Dolores Ibárruri fue útil para construir una imagen del retorno, así como para dotar de una legitimación al proyecto político que se ponía en marcha, no puede ser pasado por alto si pretendemos entender cómo se fue modulando este relato. Es cierto que el papel jugado por los medios de comunicación, en plena expansión durante esos agitados años, tampoco debe ser exagerado al extremo. El asentamiento de imaginarios y de discursos que sirven para comprender la complejidad de los procesos sociales no depende exclusivamente de ellos. Pero es indudable que su función resulta esencial para entender los valores, los temores, las aspiraciones y las ideas que se derivan de un contexto histórico específico. Dos actos, celebrados con dos meses de diferencia y que, en realidad, duraron apenas unos breves minutos, fueron ampliamente comentados, grabados, reproducidos y reelaborados para dotar de un sentido fuerte a una determinada narrativa de la transición. Estas imágenes migraron posteriormente por multitud de programas, reportajes televisivos, documentales, crónicas audiovisuales o informativos hasta convertirse en parte del repertorio de emblemas en los que se condensaba iconográficamente un proceso caracterizado por su inmensa complejidad e incertidumbre.

Dolores Ibárruri pudo cumplir una función importante en esa iconografía por su carisma y su bagaje político que resultaba muy conveniente para legitimar el proceso. En este sentido, es particularmente relevante que el carisma de una figura política que forjó su potencia simbólica en un momento histórico anterior pueda ser reciclado en otro momento histórico completamente diferente y con unos fines igualmente diversos. Este proceso de adaptación al nuevo contexto del valor simbólico de un líder nos puede dar a entender algunos rasgos del funcionamiento del carisma y su relación con los medios de comunicación. Y no debemos olvidar que el contexto de la transición democrática en España fue particularmente intenso en la forja y hundimiento de líderes políticos más o menos carismáticos. Muchos de sus protagonistas vieron trituradas sus carreras políticas en cuestión de meses o años. La gran aportación del carisma de Pasionaria al proceso, como hemos visto, puede ser condensada prácticamente en sesenta días. Pero comparativamente, hay que tener en cuenta que la fulminante relación de Suárez con el poder apenas duró cinco años. Después de su paso por las Cortes, Pasionaria se fue centrando cada vez más en su vida familiar. Mantuvo una presencia siempre fiel a la dirección de un PCE, arrastrado esos años por convulsiones 
internas cada vez más profundas. Fue un símbolo intocable tras la defenestración de Carrillo, durante el mandato de Gerardo Iglesias y también durante el de Julio Anguita. Sus aniversarios siguieron dando pie a homenajes y celebraciones, sobre todo cuando llegó a los 90 años. El poder simbólico que la acompañó hasta el final quedó reflejado en su multitudinario entierro. Podríamos afirmar que ni siquiera hoy, a 25 años de su fallecimiento, se ha disipado del todo.

\section{Referencias bibliográficas}

AGUILAR, Paloma (1996): Memoria y olvido de la guerra civil española. Madrid, Alianza Editorial.

BENET, Vicente J. (2013): "La imagen de Pasionaria en los años setenta: un caso de reciclaje del carisma en procesos de transición política". Iberic@l,4, pp.41-52.

CRUZ, Rafael (1999): Pasionaria. Dolores Ibárruri. Historia y simbolo. Madrid, Biblioteca Nueva.

FALCÓN, Irene (con la colaboración de Manuel Jiménez y Jesús Montero) (1996): Asalto a los cielos. Mi vida junto a Pasionaria. Madrid, Temas de Hoy.

GALLEGO, Ferrán (2008): El mito de la transición. La crisis del franquismo y los orígenes de la democracia. Barcelona, Crítica.

GARCÍA CASTILLEJO, Ángel I. (1995): En el parlamento y en la calle. Dolores Ibárruri diputada. Madrid, Fundación Dolores Ibárruri.

GINARD I FERÓN, David (2013): "La madre de todos los camaradas. Dolores Ibárruri como símbolo movilizador de la Guerra Civil a la transición postfranquista". Ayer, 90:2, pp. 189-216.

IBÁRRURI, Dolores (1985): Memorias de Dolores Ibárruri Pasionaria: la lucha y la vida. Barcelona, Planeta.

JULIÁ, Santos (2006): "Memoria, historia y política de un pasado de guerra y dictadura", en JuliÁ, Santos (coord.): Memoria de la guerra y del franquismo. Madrid, Taurus.

LOW, Robert (1992): La Pasionaria. The Spanish Firebrand. London, Hutchinson.

MELCHOR, Federico (1976): "El 80 aniversario de Dolores Ibárruri. Una vida para un pueblo, para un combate y un ideal". Nuestra Bandera, 83, pp. 38-42.

MORÁN, Gregorio (1986): Miseria y grandeza del Partido Comunista de España. Barcelona, Planeta.

MORÁN, Gregorio (1991): El precio de la transición. Barcelona, Planeta.

NÚÑEZ SEIXAS, Xosé-Manoel y FARALDO, José María (2009): “The First Great Patriotic War: Spanish Communists and Nationalism, 1936-1939". Nationalities Papers, 37:4, 401-424.

PÀMIES, Teresa (1976): Una española llamada Dolores Ibárruri. Barcelona, Martínez Roca. 
ROIG, Montserrat (1980): "La Pasionaria: un mineral cálido", en ¿Tiempo de mujer? Barcelona, Plaza y Janés.

RUEDA LAFFOND, Juan Carlos (2013): “ ¿Un pasado que no cesa? Discurso patrimonial y memoria pública comunista en el franquismo y la transición española". Revista de estudios sociales, 47.

SÁNCHEZ BIOSCA, Vicente (2014): "Santiago Carrillo 1971. Políticas en transición y transferencia carismática". Kamchatka, 4, 165-188.

VÁZQUEZ MONTALBÁN, Manuel (2005 [1995]): Pasionaria y los siete enanitos. Barcelona, Debolsillo.

Vicente J. Benet es Catedrático de Comunicación Audiovisual en la Universitat Jaume I de Castelló. Es autor, entre otros libros, de El cine español. Una historia cultural (Paidós, 2012) así como de numerosas publicaciones en revistas nacionales e internacionales. Ha sido profesor invitado en varias universidades, entre otras Chicago, Pennsylvania, Cambridge o la Sorbona. 